UDC 94(477=162.1)“1917/1918”

DOI: 10.24919/2519-058x.14.197181

\title{
Tamara LOZYNSKA
}

PhD hab. (Public Administration), Professor, Head of the Department of Public Administration of Poltava State Agrarian Academy, 1/3 Skovorody Street, Poltava, Ukraine, postal code 36000 (tnloz@rambler.ru)

ORCID: https://orcid.org/0000-0003-2858-9374

ResearcherID: S-4703-2016 (https://publons.com/researcher/2176326/tamara-lozynska/)

\section{Tetiana SHCHETININA}

PhD (History), Docent, Associate Professor of the Department of Public Administration of Poltava State Agrarian Academy, 1/3 Skovorody Street, Poltava, Ukraine, postal code 36000 (t.schetinina@rambler.ru)

ORCID: https://orcid.org/0000-0003-2886-0929

ResearcherID: C-5682-2017 (https://publons.com/researcher/C-5682-2017/)

\section{Тамара ЛОЗИНСЬКА}

доктор наук з державного управління, професор, завідувач кафедри публічного управління та адміністрування Полтавської державної агарної академії, Полтава, вул. Г. Сковороди, 1/3, Україна, індекс 36000 (tnloz@rambler.ru)

\section{Тетяна ЩЕТІНІНА}

кандидат історичних наук, дочент, доцент кафедри публічного управління та адміністрування Полтавської державної агарної академії, Полтава, вул. Г. Сковороди, 1/3, Україна, індекс 36000 (t.schetinina@rambler.ru)

Бібліографічний опис статті: Lozynska, T. \& Shchetinina, T. (2020). General Secretariat (Ministry) for Polish affairs of Ukrainian People's Republic at the time of the Central Rada: formation stages and structure development. Skhidnoievropeiskyi Istorychnyi Visnyk [East European Historical Bulletin], 14, 86-98. doi: 10.24919/2519-058x.14.197181

\section{GENERAL SECRETARIAT (MINISTRY) FOR POLISH AFFAIRS OF UKRAINIAN PEOPLE'S REPUBLIC AT THE TIME OF THE CENTRAL RADA: FORMATION STAGES AND STRUCTURE DEVELOPMENT}

\begin{abstract}
The Purpose of the Research. However, there is still no separate article that would comprehensively cover the process of structural formation of the Polish minority office as a central executive body. Therefore, the purpose of the article is to study the structure formation and development process of the General Secretariat (Ministry) for Polish affairs of the UPR. The research methodology is based on the principles of scientific knowledge, objectivity, historicism and general scientific (analysis, synthesis, comparison) and special-historical methods (comparative-historical, historical-systemic). The Research Novelty. For the first time, the process of structural formation of the Polish minority office as the central executive body was systematized, and the stages of this process were determined. The Conclusions. The General Secretariat (Ministry) for Polish affairs of the Ukrainian People's Republic (the UPR) went from a structural unit within the General Secretariat of Interethnic (Foreign) Affairs
\end{abstract}


to a separate central body of an executive power. The establishment formation was closely interrelated with the development process of Ukrainian statehood on the path to independence. This made it possible to single out two periods in the establishment formation, to determine their chronological framework, and also to identify two stages of this institution organizational development during the second period. The structure of the general secretariat (ministry) for Polish affairs of the Ukrainian People's Republic reflected the activities that were most relevant to the ethnic Poles, who lived in Ukraine. The most successful was the work of the establishment in support of Polish school education. At the same time, some tasks, such as the creation of the national unions for the implementation of the national personal autonomy principles, could not be implemented. The general secretariat (ministry) for Polish affairs of the UPR was able to act effectively thanks largely to its leader, M. Mickiewicz, and the well-chosen staff.

Key words: the Central Rada, national minorities, the Poles, authorities, the General Secretariat (Ministry) for Polish affairs of the UPR, structure, establishment, department.

\title{
ГЕНЕРАЛЬНЕ СЕКРЕТАРСТВО (МННСТЕРСТВО) З ПОЛЬСЬКИХ СПРАВ УНР ЗА ДОБИ ЦЕНТРАЛЬНОЇ РАДИ: ЕТАПИ ФОРМУВАННЯ ТА РОЗВИТОК СТРУКТУРИ
}

\begin{abstract}
Анотація. Мета дослідження - виявлення прочесу формування і розвитку структури генерального секретарства (міністерства) з польських справ УНР за доби Центральної Ради та визначення етапів його становлення. Методологія дослідження побудована на принципах науковості, історизму, об'єктивності, що дало змогу реалізувати загальнонаукові методи аналізу, синтезу й узагальнення. Особливості структури відомства з польських справ у продовж діяльності Української Центральної Ради розкрито, спираючись на порівняльно-історичний та історико-системний методи. Наукова новизна полягає у тому, що вперше здійснено спробу систематизувати прочес структурного становлення відомства у справах польської меншини як центрального органу виконавчої влади, визначивщи етапи иъого процесу. Висновки. У своєму розвитку відомство пройшло шлях від структурного підрозділу у складі генерального секретарства міжнаціональних (міжнародних) справ до окремого центрального органу виконавчої влади. Становлення відомства було пов'язане з прочесом розвитку украӥнської державності на иляху до незалежності. Структура генерального секретарства (міністерства) з польських справ УНР відображала напрями діяльності, які були найактуальнішими для етнічних поляків, що мешкали в Украӥні. Найбільш успішною виявилася діяльність відомства, спрямована на підтримку польської шкільної освіти. Водночас деякі завдання, як наприклад, створення національних союзів для реалізачї принципів національно-персональної автономії, втілити у життя не вдалося. Генеральне секретарство (міністерство) з польських справ УНР діяло результативно, завдячуючи своєму керівникові - М. Мічкевичу та добре підібраному кадровому складу.

Ключові слова: Центральна Рада, національні меншини, поляки, генеральне секретарство (міністерство) з польських справ УНР, органи влади, структура, відомство, департамент.
\end{abstract}

The Problem Statement. The historical events that took place in the Ukrainian lands during the days of the Central Rada (1917 - 1918) can be unequivocally attributed to the most researched by scientists. This long-lasting interest is explained by the exceptional place of the first experience of a national statehood formation in Ukraine in the XXth century. The large number of sources and the constant updating of the scientific investigations allow the researchers to cover the events and characterize the processes that lasted from March 1917 till April 1918 more thoroughly. A certain tendency for detailing the researches is observed concerning the authorities and administrations that functioned at that time. If at the initial stage the Ukrainian Central Council was of great interest of scientists and the general public, in some period of time, the attention was paid to the work of the Government (Secretariat-General), its individual general secretariats (ministries), the activities of the local governments, public organizations and movements. 
A special place among the central executive bodies during the period of the Central Rada is occupied by the offices for the national minorities affairs - secretariats (ministries) for the Jewish, Polish and Russian affairs of the UPR. The short period of their existence and the atypical nature of their activities, determined by the range of problems of a particular nation, aroused a considerable interest of the scientists in the activity of these departments. At the same time, their activities were considered by the scientists in the context of the history of the correspondent nations, their socio-political activities, the ethno-political processes of that era, the peculiarities of humanitarian politics, etc. In accordance with this approach, the information on the structure formation and the activities foundations of the secretariats (ministries) for the national minorities affairs turned out to be somewhat scattered, fragmentary, which actualizes the issue of its systematization.

The specific nature of the activities of the national minority offices makes it impossible to compare their structure with that of other central executive bodies during the period of the Central Rada. As for comparing the formation structure of the national minority offices with each other, it will only emphasize their "individuality", the variety of tasks that were set up for individual national minorities in Ukraine of that period, as well as the difference in potential for implementation. Therefore, we consider it appropriate to analyze a specific office for the national minorities in the course of its administrative and organizational transformation. In this context, the most appropriate is the analysis of changes in the structure of the General Secretariat (Ministry) for the Polish affairs of the UPR.

The Analysis of Recent Research and Publications. The Ukrainian historians created a powerful array of the scientific works, dedicated to the Central Rada, a leading place among which are V. Verstyuk's studies (Verstyuk, 1997; Verstyuk, 2017), V. Soldatenko's studies (Soldatenko, 2008; Soldatenko, 2010; Soldatenko, 2011), O. Reyent's studies (Reyent, 2016).

From the whole range of the scientific researches, only those works were singled out, which covered the aspects of the structure formation of the General Secretariat (Ministry) for Polish affairs of the UPR. This fact greatly narrowed the scope of the research and allowed us to single out a number of works by O. Bilobovets (Bilobovets, 2018), T. Zaretska (Zaretska, 2003), O. Kalakura (Kalakura, 2007), M. Lazarovych (Lazarovych, 2013), V. Skalsky (Skalsky, 2008), M. Potapenko (Potapenko, 2010). A brief review of the basic elements of the departments structure for national minorities, including the Poles, was presented by O. Myronenko in the reference and encyclopedic publications (Myronenko, 1996; Myronenko, 1997).

A special place is occupied by the scientific work of A. Kudlay (Kudlay, 2008), dedicated to an in-depth analysis of the activities of the office for international affairs, which for some time included the Polish affairs office.

The integrity of the investigated issue is substantially supplemented by the archival documents, including those recently introduced into the scientific circulation by the experts (Lebedieva, 2015), and the materials of the press of that period.

The Purpose of the Research. However, there is still no separate article that would comprehensively cover the process of structural formation of the Polish minority office as a central executive body. Therefore, the purpose of the article is to study the structure formation and development process of the General Secretariat (Ministry) for Polish affairs of the UPR during the period of the Central Rada and to determine the stages of this formation.

The Statement of the Basic Material. Nowadays, it is almost a textbook fact that the very idea of protecting the rights of the national minorities was normalized during the period of the Ukrainian Central Rada (Council) (the law on national and personal autonomy - 1917, 
January 9 (22), the Constitution of the UPR - 1918, April 29 (section VIII "National Unions")) and put it into practice by means of the creation of the appropriate central executive bodies for the affairs of the national minorities.

The activities of the General Secretariat (Ministry) for Polish affairs of the UPR reflected fully the complexity of the historical moment and the peculiarities of the socio-political life of the Poles of Ukraine. According to the statistics department data of Kyiv city government, in April 1918, the Poles were the least assimilated nation. In the course of that study, it was found out that among 42,821 interviewed people 38495 (89,8\%) spoke their mother tongue-Polish. For comparison: this figure among the Ukrainians - 75,1 \% (of 56225 persons - 42 220), among the Jews $-70,5 \%$ (of 87246 persons - 61516 spoke Yiddish) (Po dannym statisticheskogo otdela kievskoy gorodskoy upravy, 1918). Such a high level of a national self-identification helped the Poles to perceive really their position in Ukrainian society at that time.

It should be noted that the establishment of departments for the Jewish, the Polish and the Russian nations took place simultaneously. We consider it appropriate to divide this process into two periods during which the significant changes in the structure, the tasks and the staff of the offices took place, in particular:

1. The formation as a structural unit of the central executive body-Vice-Secretariat of the General Secretariat of National (International) Affairs of the UPR.

2. The activity in the governmental structure in the status of a separate office - the General Secretariat, and subsequently - the Ministry.

With the formation of the General Secretariat as a governmental institution on June 15, 1917 , long-lasting work began on the formation of the central executive bodies in Ukraine, including in the affairs for the national minorities. The importance of attitude to the minority community is evidenced by the fact that at the meeting of the Minor Council on July 15, 1917, the Secretariat for international affairs was suggested being called "the Secretariat for the protection of the rights of the national minorities", and not one but two representatives from each nationality were submitted (Verstyuk, 1996, p. 179). The following day, the Charter of the Supreme Administration of Ukraine was adopted by the Minor Council, Item 4 of which established the General Secretariat of International Affairs and determined the posts of three comrades of the Head of the Office for the affairs of the Jews, the Poles and the Russians.

In fact, from July 16, 1917, the first stage of the formation and activity of the national minority offices began, during which they were structurally linked to the UPR General Secretariat for National (International) Affairs. On this basis, it is appropriate to refer to the work of O. B. Kudlay. The scientist investigates the activities of the General Secretariat thoroughly, and one of the sections of the work is directly devoted to the organization of the internal structure (Kudlay, 2008, pp. 9-21).

The researcher elucidates the content of the "Regulation on the Secretariat-General for National Affairs", which defines the principles of activity of both the Secretariat itself and the limits of the competence of the Vice-Secretariats for national minorities: the participation in meetings of the General Secretariat with an advisory vote; the right to cast a decisive vote on matters within their sphere of competence; all orders of the Secretariat-General and its organs concerning the domestic life and rights of the national minorities will be issued only after they have been referred by their respective companions of the Secretary-General for National Affairs; the language of the domestic use must be the language of a particular national minority; the posts of the local commissioners for national affairs were introduced (Kudlay, 2008, p. 16). 
According to O. B. Kudlay, "this document is a more detailed recapitulation of the Secretary-General's order on the interethnic affairs to the secretary's comrades of July 27, 1917" (Kudlay, 2008, p. 15). We consider it necessary to specify that the order, consisting of nine paragraphs and approved by O. Shulgin - the head of the General Secretariat for National Affairs (the name of the Office as in July 1917), indicated the date of July 22, 1917. On the document there is a manuscript record about its correspondence to the original, signed by P. Khrystyuk, a general clerk, and dated July 29, 1917. (Central State Archive of the Higher Authorities and Administration of Ukraine - CSAHAAU, f. 2592, d. 1, c. 67, p. 4).

The confirmation of such a date and an explanation of its occurrence can be found in another archival document - "the Draft Instruction on the appointment of Comrade Secretary-General for national affairs and their functions" (CSAHAAU, f. 1748, d. 1, c. 3, pp. 1-16). The document is stored in the fund of the Ministry of Jewish Affairs of the UPR. The text of the order is also given and an interesting commentary is given on its occurrence. It is noted that at the first meeting of the Secretary-General for National Affairs with his companions from the national minorities the question arose about the tasks and essence of the activities of these offices. After several meetings, the order was approved in the version, proposed by a companion, who dealt with the Jewish affairs (CSAHAAU, f. 1748, d. 1, c. 3, p. 3).

It is noted that after the order was signed on 22 July 1917 by the Secretary-General for National Affairs, the work on the document was continued because of its specific legal nature. By its legal nature, the order was directed by the head of the department to his subordinates. That fact raised concerns that the change in leadership might cause significant changes in the order itself or its complete cancellation, "simultaneously changing the very nature and competence" of the post of comrade secretary for the national minorities (CSAHAAU, f. 1748, d. 1, c. 3, p. 9).

Taking into account the situation objectively, the Secretary's companions for the national minorities suggested that the order be approved not by their department, but by the General Secretariat. In favour of such an approach there was the very content of the order, some provisions of which essentially went beyond the competence of the General Secretariat for National Affairs. In particular, this concerned a number of issues that were of a national nature: the official language of communication in the apparatus of a comrade for national affairs, the appearance of normative legal acts of other secretariats, if they concern the inner affairs of the correspondent nation, etc. In the end, the government decided that both the Secretary-General for national affairs and his two comrades (for Jewish and Polish affairs, since the Comrade Secretary for Russian affairs would only join in October 1917) would receive this order from the Clerk as the extract from the protocol of the General Secretariat meeting of 25 July 1917 (CSAHAAU, f. 1748, d. 1, c. 3, p. 10).

We should emphasize that the very order was the primary document, the content of which was included into the text "Regulation on the General Secretariat for National Affairs". The author of the "Draft of Instruction ..." wrote quite rightly that such attention to the order was dictated by the presence in its content the elements of a national personal autonomy (CSAHAAU, f. 1748 , d. 1, c. 3, p. 8). Prior to the adoption of the relevant law, the basic rules for the protection of the national minorities rights were formulated in the decree and subsequently were included into the "Provisions".

Some more important nuances should be noted, based on the test of "Draft of Instruction ...". Firstly, their author uses the term "vice-secretariat" as the name for for the national minorities offices, which is quite common in the scientific literature and memoirs. In all legal acts of that period, the official title of the post is that of a Comrade Secretary-General, and the 
name of the Office is not actually used, because it is rather the Office of Comrade SecretaryGeneral. Secondly, in the "Drafts of Instruction...", the first attempt was made to systematize the work on the establishment of offices for the national minorities. From the test of the document it is not clear whether the author divides the direct activities of the department into stages, or simply delineates the material itself. Nevertheless, the text of "Drafts of Instruction ..." is divided into the stages or blocks: the first one is untitled, indicated by the period: July, 15 - September 1, 1917; the second one is entitled "Determination of the Competence of the Vice-Secretariat for National Affairs" and is dated: September, 1-25 October, 25 (CSAHAAU, f. 1748, d. 1, c. 3, pp. 1, 9). From the content of the document, it follows that a certain criterion for such a division into stages was the normalization of the status of comrades in the affairs for the national minorities. It should be also noted that the starting date of the first stage, specified in the archival document, is in a full correspondence with the date proposed by us - July 16, 1917.

Analyzing the "Regulation on the Secretariat-General for National Affairs", it should be noted that, unlike the order, it contains more data on the structure of the Vice-Secretariats: each secretary's companion had his own office; three national councils were set up under authority of Secretary's Comrades (Kudlay, 2008, p. 16).

The activities of the Vice-Secretariats for National Minorities, O. B. Kudlay, analyzes on the example of the Polish Affairs Office. Based on the report of Comrade Secretary, the researcher notes that in the autumn of 1917, in the Vice-Secretariat there functioned:

- the department for education: it was engaged in collecting the data on pupils and compiling appropriate questionnaires, analyzing them for the organization of school education of the Poles; a Board of Education was created to involve specialists in this matter, which established Polish teachers' seminary to train teachers for Polish elementary schools;

- the economic department, concerning which we have only a generalized formulation - "it collected the data on the economic needs of the Polish people";

- the general department "handled the current issues, the government orders and elaborated the law on the use of the national minority languages" (Kudlay, 2008, p. 17).

V. Skalsky gives the detailed information on this period of the Office work: "The organization of the Vice-Secretariat work lasted for a long time. It started functioning only in October 1917" (Skalsky, 2008, p. 195). The researcher points out that "the informal head of the institution, who supervised all the cases was E. Starchevsky, who, for some reason, preferred not to participate in the work of the Vice-Secretariat officially" (Skalsky, 2008, p. 195).

The deputy secretary and head of the General Office was Roman Knoll. From the latter it follows that in the structure of the department, in addition to the above mentioned departments, a general office was created. V. Skalsky's information is full of personalized data and certain clarifications, in particular, regarding the names of departments: not "general" but "general affairs"; not "economic" but "economic cooperative". The scientist indicates the names of the heads of departments (the general affairs department - J. Starchevsky, the economic and cooperative department $-Z$. Petkevych, the department for education - S. Kalinovsky) and the names of the individual employees of the education department: L. Groholsky, G. Ulashyn, G. Yuzefsky, V. Gunter and B. Ivinsky (Skalsky, 2008, p. 195).

As for the characteristics of the activities of these departments, the work of the education department is recognized as "rather theoretical", and the work of the general department "was limited to the attemps to protect persons of Polish descent from requisitions and pogroms". The mechanism of such protection was the provision of monument security 
documents for the Polish estates. "Moreover, it was done without any analysis of their true value. Such massive fabrication of documents led to the levelling of the very concept of monument" (Skalsky, 2008, p. 195).

Describing the activities of the Vice-Secretariat as a whole, O. B. Kudlay notes that "the very work of the Polish "department" of the secretariat was still at the stage of organization, but more Poles turned to it for help in their own affairs" (Kudlay, 2008, p. 17). Such a conclusion does not coincide with the opinion expressed by V. Skalsky, who emphasizes that "the Polish minority had two forms of autonomy in the Ukrainian lands. The first one - by means of a state-legitimized but of a low-impact Vice-Secretariat for Polish Affairs within the Secretariat-General. The second one - by means of the PEC, which was essentially a state in the state, with its local authorities, the tax system and the armed forces" (Skalsky, 2008, p. 195).

Under the abbreviation "PEC" we mean the Polish Executive Committee in Rus, which was formed in Kyiv on March 6, 1917, at the Congress of all Polish public organizations (the representatives of 39 organizations were present) and communities in several provinces of Ukraine (Potapenko, 2010, p. 92). In fact, it was a powerful socio-political association that created its own structures quickly, including the local areas. It aimed at protecting the rights and representing the interests of the Poles in Ukraine and it was well known to the Polish public both in the capital and in the province. In this rivalry, the competitive advantages were not on the side of the Polish Secretariat for Polish Affairs.

In fact, from the time of its creation and throughout the period of existence during the days of the Central Rada (Council) for the Polish Affairs Office, its permanent leader was Mieczysław (Vyacheslav) Kazimierzowicz Mickiewicz, whose biography was published in 1918 in an abridged form. He was born in 1879 in the town of Kamianets-Podilsky in the family of a government official, and he received his secondary education in the same city. He graduated from the Law Faculty of Odesa University in 1904. In the same year he joined the Lawyers' Association and started a rather successful professional activity. Since his studies at the university, he joined the "secret democratic Polish organizations", for the cooperation with which he was arrested in St. Petersburg in 1907 (Pro Tsentralnu Radu i Radu Narodnykh Ministriv, 1918, pp. 87-88). Such a professional and revolutionary experience only added to M. Mickiewicz the socio-political weight and promoted him to a high-level position in the General Secretariat. While working for the Ukrainian civil service, he remained a Polish public figure at the same time. That is why he reacted sharply to the provisions of the Third Universal of the Central Rada concerning the land issue and caused a negative reaction of some Polish politicians. It is known that in connection with these events M. Mickiewicz resigned, but in a month he returned to the government work and headed the Polish Affairs department until its liquidation.

In the course of this first stage of the departments establishment for the national minorities the issue of payment for the Vice-Secretaries was also solved. From July 15 to August 1, 2017 M. Mickiewicz and his Jewish colleagues were assigned 250 rubles each, and for the work during August - 500 rubles each (CSAHAAU, f. 2592, d. 2, c. 6, p. 9). Based on the archival documents, which were not so long ago introduced into the scientific circulation by I. Lebedeva, we can compare the data concerning the amount of salary payment in other departments. For example, the amount of salary of the Secretary General for Land Affairs for one and a half month was 750 rubles, i.e., 500 rubles per month (Lebedeva, 2015, p. 113); the salary of the Secretary General for Education for the period from June 25 till August 1, i.e., for 37 days, was 600 rubles (Lebedeva, 2015, p. 114). The analysis of tha salaries illustrates 
the following: the salary of the Vice-Secretaries corresponded to the amount of salaries of the individual Secretaries-General. The very fact also emphasized their much higher status as compared to the status of the average deputy heads of the departments.

With the proclamation of the Ukrainian People's Republic on November 7, 1917, at the Third Universal of the Central Rada, the status of the national minority offices, including the Polish Vice-Secretariat, rose to the level of other general secretariats as central executive authorities. The Change of the status of the office gives us grounds to consider it as the second stage in the process of its establishment. As for determining the initial date of functioning of the new secretariat-general, we suggest focusing on November 27, 1917, because it was on this day that Order No. 1 of the reorganized office agency was dated (Prykazy po Sekretarstvu Polskykh Sprav, 1917). The very next day, on November 28, 1917, at the meeting of the General Secretariat, M. Mickiewicz was appointed the Secretary General for Polish Affairs. This fact is registered in the protocol. On that day, the personnel issue of the department's work was considered, and V. L. Rudnytsky was appointed the deputy of the Secretary General on the advice of M. Mickiewicz (Verstyuk, 1996, p. 482), who actually began performing his duties earlier - from November 22, 1917 (Прикази 1917). Beginning from December 1917 and spring 1918, V. L. Rudnytsky regularly substituted M. Mickiewicz at the government meetings. On his submission (at the meeting of Ministers' Council on March 27, 1918) it was approved to "give days-off to Catholic government officials for two days" on the occasion of the Easter celebration (Verstyuk, 1996, p. 235). It's true, this fact caused a wave of indignation in the press. The newspaper "The Renaissance" wrote that the Catholics lived among the Ukrainians, but such governmental decree did not concern the Ukrainians (Pryvileiovana volia viry, 1918).

Investigating the structural changes in the Secretariat-General for the Polish affairs of the UPR, it should be noted that its divisions also increased their status: the former deputy secretariats were reformatted into departments, and later on into units. In fact, during the period of activity of the General Secretariat for Polish Affairs of the UPR (December 1917 - the beginning of January 1918), the departments of the General Office and the Department for Education functioned. The General Office was the most complete with a clear hierarchy of posts. According to Order No. 1 of the General Secretariat for Polish Affairs of the UPR of November 27, 1917, the following persons started working in the department: Jan Starchevsky a clerk of the office, Kazimierz Domoslawski - an assistant clerk of the office, the 2nd-grade clerks - Titus Poplowski, Franz Jaworski, Maria Kochler, the office clerks of the 3rd rank Claudia Ushakova, Wanda Petkevich (Prykazy po Sekretarstvu Polskykh Sprav, 1917).

According to the same Order No. 1, Zenon Petkevich was given the post of the clerk "with the scope of activity - the head of the statistical and economic department". Under the name of "the economic cooperative department", this unit functioned in the structure of the Vice-Secretariat under its leadership. Later on, the department, headed by Zenon Petkevich, was transferred to the newly created department of the national self-government (Skalsky, 2008, p. 196).

In addition, there was a military department of the General Office and Stanislav Hrabiansky was appointed the military commissar, i.e., the chief of the staff, and his assistant Stanislav Petkevich, the ensign, and later on Leonard Stanishevsky was appointed the clerk of the department (Order No. 4, December 2, 1917) (Prykazy po Sekretarstvu Polskykh Sprav, 1917). During this period, the department of the General Office also included the Press and Information Department (Myronenko, 1995, p. 158). In the spring of 1918 this department didn't exist in the structure of the Polish department. 
The Department for Public Education of the General Secretariat for Polish Affairs of the UPR had a structure that clearly reflected the main areas of its work: the elementary school department (G. Ulashyn), the secondary school department (M. Kulczycki), the extracurricular department (V. Matuszewski), the technical department and applied arts (O. Sosnovsky), the department for culture and arts (L. Groholsky) (Lazarovych, 2013, pp. 216-217; Skalsky, 2008, pp. 197-198). S. Kalinovsky was in charge of this department (he headed this department in the Vice-Secretariat, his appointment was renewed on November 27, 1917). In one of the departments for education Antonina Kryzhanivska became the office clerk of the 3rd category (according to Order No. 4, December 2, 1917) (Prykazy po Sekretarstvu Polskykh Sprav, 1917). The structure of the department for education remained unchanged throughout the lifetime of the department.

According to Order No. 4, in the departments of the General Secretariat for Polish Affairs the clerical officials came to offices: Olgerd Izdebsky, Kazimierz Jelowiecki, Richard Mikulla, Elena Dombrowska, Tadej Manieczewski. The information on the staff of the department can be obtained owing to a certain political tendency for publicity in the work of government agencies. In particular, the departmental orders, entirely concerning the personnel issues, were published in December issue of "The Bulletin of the UPR Secretariat-General" (1917). (Prykazy po Sekretarstvu Polskykh Sprav, 1917).

The declaration of independence of the UPR on January 9, 1918 at the IVth Universal of the Central Rada was accompanied by the reorganization of the General Secretariat into the Council of People's Ministers, and, accordingly, the General Secretariats were transformed into Ministries. We do not single out this period of the department formation into a separate stage, because the department continued its activity as an independent administrative unit, but at a new level. On January 13, 1918, the department of a national self-government was established in an updated agency to implement the principles of the law on a national and personal autonomy. The department was set up the task to work on summoning the Polish Constituent Assembly in Ukraine and the organization of the Polish National Council (Union). At first, the department was headed by Leon Třecyak, a lawyer, and later on by K. Rozhnevich. The latter headed the organizational unit of this department. Z. Milkevich was his deputy in the department (Skalsky, 2008, p. 197). In contrast to the Ministries of Jewish and Russian affairs, the Polish Ministry did not suppress the organization of the National Council. According to contemporaries, the problem consisied in "the reluctance of conservative groups, which make up a significant percentage in the Polish society", to promote the work (Protest poliakiv, 1917).

The activity of the Ministry of Polish Affairs of the UPR was interrupted by the Bolshevik invasion in January-February 1918. The department was not evacuated and remained in the capital with the leaders: M. Mickiewicz, V. L. Rudnitsky, S. Kalinovsky.The Ministry's premises were destroyed during the fighting and the part of the documents was destroyed too. The military and statistical economic departments were hit the hardest (Bilobrovets, 2018, pp. 78-79).

After the return of the Ukrainian authorities to Kyiv in the government, headed by V. Holubovych, the portfolios of the national ministries were "reserved" but lacked actual filling. And only on April 9, 1918, at a meeting of the Minor Council, a separate question "On the approval of ministers for Jewish and Polish affairs" was considered. The Ministers were approved at the request of the Prime Minister (Verstyuk, 1997, p. 259). Although the formal appointment of the authority of the department was delayed for a long time, it did not pre- 
vent from improving of the ministry organization. It was at this time that the general office grew into a full-fledged department, headed by L. Třecyak, and had the following structure: a personal staff department (K. Domoslawsky), a business department (an accountant K. Jelowitsky; a cashier - B. Rozvodowsky), a general department (J. Starchewsky), a legal department (a legal adviser - P. Khojnowsky) (Skalsky, 2008, p. 198), a military department (acting chief - S. Grabiansky) (Bilobrovets, 2018, p. 81). Concerning the post of a legal adviser, in March 1918 it was occupied by Ivan Karlovych Navrochynsky, who was recommended to the Supreme Court of Appeal of the UPR during the same period (CSAHAAU, f. 1115 , d. 1 , c. 6, p. 42 ).

In April 1918, the official governmental publication "Visnyk Rady Narodnykh Ministriv UNR" ("Bulletin of the Council of People's Ministers of the UPR") published the structure list of the Ministry of Polish Affairs (Pobudova ministerstva, 1918). The department had 80 employees at that time (Kalakura, 2007, p. 129; Bilobrovets, 2018, p. 81), and its budget was 41100 rubles per month (Zaretska, 2003, p. 183). At the same time, a large article was published on the pages of the newspaper "Narodnoye Delo" in the Ministry of Polish Affairs, which can be called a detailed report on the work of the department (В министерстве 1918). In the context of this research, the article is interesting in the fact that it was mentioned about the functioning in the department of the General Chancellery of another department - in the sphere of "cultural needs of refugees". This department of the Ministry cooperated with the refugee department of the Ministry of the Interior Affairs of the UPR. The authors of the article reported that, according to the national agency, up to 300,000 Polish refugees gathered on the borders with Poland, whom the German military authorities did not allow to return home. The refugees' condition was "tragic and there are many cases of starvation" (V ministerstve po polskim delam, 1918). In the studies on the refugee problems we do not find the confirmation fact for functioning of this department, although it is clear that the number of refugees among the Polish population was considerable. But, as L. Zhvanko points out, an appeal to the Polish department took place back in December 1917 when its representative was invited to a special commission on refugee affairs, organized by the UPR Secretariat-General for International Affairs (Zhvanko, 2013, p. 162).

The Ministry of Polish Affairs of the UPR ceased to function in accordance with the law of Hetman P Skoropadsky of July 9, 1918. This act terminated the law on a national and personal autonomy and abolished the ministries of the national minorities. It was decided to submit the materials of these departments for culture and education to the Ministry of Public Education and other documents - to the Ministry of Internal Affairs. The latter was instructed to set up a special commission in its Department of General Affairs to carry out the liquidation proceedings. The clercs of the offices, including those, who specialized in Polish cases, who were not appointed to the civil service, received a financial aid in the amount of a two months' salary (CSAHAAU, f. 3690, d. 1, c. 13, p. 8).

During the liquidation of the Ministry, Professor G. Ulashiyn, a Slavic scholar of a Polish origin, addressed to the Ukrainian authorities with an open letter. After the liquidation of the department, he requested to keep the Polish Department for Education as a separate unit, because its work was so important as well as the influence on the educational environment of the Poles in Ukraine (Zaretska, 2003, p. 184).

The liquidation of the Ministry, the date of adoption of the relevant legislative act, July 9 , 1918 , is the end of the second period of the Office activity according to the periodization, suggested by us. It is noteworthy that the Ministry functioned for several months longer than the Central Council itself. 
As mentioned above, in the course of its activities, the Polish Affairs Office had a significant competitive influence on the part of the departments formed by the Polish democratic organizations. M. Potapenko divided the process of development of the Polish democratic movement in the Dnieper Ukraine into three stages: "1. March - the middle of June 1917: the formation of a network of legal departments of the Polish democratic movement. 2. The middle of June till the beginning of November 1917: the unification of the Polish Democratic Organizations into the Polish Democratic Central Ukraine. 3. The beginning of November 1917 - April 1918: the exacerbation of contradictions of the PDC political course in Ukraine and its split" (Potapenko, 2010, p. 102). As it can be seen, the second and third stages coincide chronologically with the periods of the formation of the Polish Affairs Office. Such synchronization is absolutely objective, since the historical influences of the large-scale changes of the Ukrainian Revolution were decisive. As for the third stage of the development of the Polish democratic forces, which was marked by a split and a recession in their activities, it is inversely proportional to the development of the Polish Affairs Office at the same time. This is explained by the significant changes in the status of the General Secretariat (Ministry) of the Polish affairs of the UPR as a governmental institution with a clear structure, a recognized leadership, a professional staff and well-established authority among the Polish public of Ukraine. The protection of the rights and legitimate interests of the national minorities, the creation of appropriate authorities and governing bodies were a significant trend of the revolutionary era, and in practice they were to reinforce the proclaimed slogans of equality and brotherhood. The corresponding processes continued in different areas of the Ukrainian ethnic lands. In particular, in November 1918, Bukovyna National Council in Chernivtsi proclaimed the need for the formation of both legislative and executive bodies with the participation of the national minorities in the region (Vidnyanskiy, 2012, p. 26).

The Conclusions. The analysis done within the framework of this research, a number of the archival documents and the press materials show that, in fact, less than a year of hard work in Ukraine during the days of the Central Rada, the structure of the Polish Affairs Office was formed as the central executive body. The actual structural development of the department is divided into periods according to the criterion of organizational independence of this institution. Thus, the process of formation and structural establishment of the General Secretariat (Ministry) for the Polish Affairs of the UPR took place during two periods:

1. July 16, 1917 - November 26, 1917, when the Office was formed as a Vice-Secretariat within the structure of the General Secretariat for National Affairs.

2. November 27, 1917 - January 9, 1918; March 1918 - July 9, 1918, the General Secretariat (Ministry) for the Polish Affairs already functioned as an independent central body of the executive power. During this period, we single out two stages objectively - the stage of activity in the status of the General Secretariat (November 27, 1917 - January 9, 1918) and the stage of activity in the status of the Ministry (March 1918 - July 9, 1918), which was reflected on the structure and affected the personnel of the department.

The periods, singled out by us, are quite consistent with the steps of the Ukrainian state-making process: from autonomy to independence. These changes were accompanied by a constant internal improvement of the structural formation of the department. The latter was formed according to both: the standard components (for example, the general office with the departments of a legal counsel, information and press, economic, etc.), and the elements that reflected the essence of a national personal autonomy - a certain "state in the state" for the national minorities (for example, the Department for Education alongside with the General 
Secretariat (Ministry) of Education, the military department alongside with the Ukrainian military institutions, etc.). The structural apogee of the minority independence can be considered in the creation of a national self-government department, which was called to life by the relevant law and had to put into practice its basic rules.

Acknowledgments. We express sincere gratitude to all members of the editorial board for consultations provided during the preparation of the article for printing.

Funding. The authors received no financial support for the research, authorship, and/or publication of this article.

\section{BIBLIOGRAPHY}

Bilobrovets, O. M. (2018). Pozytsiia polskykh politychnykh syl v Ukraini shchodo spivpratsi z ukrainskymy orhanamy vlady (kinets 1917 - 1918 rr.) [The position of the Polish political forces in Ukraine on cooperation with the Ukrainian authorities (end of 1917 - 1918)]. Intermarum: istoriia, polityka, kultura, 5, 47-88. doi 10.33287/10185 [in Ukrainian]

Kalakura, O. Ya. (2007). Poliaky v etnopolitychnykh protsesakh na zemliakh Ukrainy u XX stolitti [Poles in ethnopolitical processes on the lands of Ukraine in the XX century]. Kyiv: Znannia Ukrainy, 508 p. [in Ukrainian]

Kudlay, O. B. (2008). Stvorennia ta diialnist narodnoho ministerstva mizhnarodnykh sprav Ukrainskoi Narodnoi Respubliky (cherven 1917 - kviten 1918 rr.) [Creation and activity of the People's Ministry of International Affairs of the Ukrainian People's Republic (June 1917 - April 1918)]. Kyiv: Instytut istorii NAN Ukrainy, 116 p. [in Ukrainian]

Lazarovych, M. (2013). Derzhavna etnopolityka doby Ukrainskoi Tsentralnoi Rady (na prykladi polskoi natsionalnoi menshyny) [State Ethnic Politics of the Ukrainian Central Rada (on the example of the Polish national minority)]. Acta Scientifi ca Academiae Ostroviensis Sectio A: Naukihumanistyczne, społeczne i techniczne. Wyższa Szkołę Biznesu i Przedsiębiorczości w Ostrowcu, (1), 207-223. [in Ukrainian]

Lebedeva, I. (2015). Pershi kroky Heneralnoho Sekretariatu (za neopublikovanymy protokolamy) [First steps of the General Secretariat (according to unpublished protocols)]. Visnyk Kyivskoho natsionalnoho linhvistychnoho universytetu. Seriia: Istoriia, ekonomika, filosofiia, (20), 105-121. [in Ukrainian]

Myronenko, O. M. (1995). Svitoch ukrainskoi derzhavnosti: polityko-pravovyi analiz diialnosti Tsentralnoi Rady [The light of the Ukrainian statehood: political and legal analysis of the activities of the Central Rada]. Kyiv, 328 p. [in Ukrainian]

Myronenko, O. M. (1996). Heneralne sekretarstvo (ministerstvo) z polskykh sprav UNR [General Secretariat (Ministry) of Polish Affairs of the UPR]. Mala entsyklopediia etnoderzhavoznavstva. Kyiv: Dovira, 942 p. [in Ukrainian]

Myronenko, O. M. (1997). Heneralne sekretarstvo (ministerstvo) z polskykh sprav UNR [General Secretariat (Ministry) of Polish Affairs of the UPR]. Ukrainske derzhavotvorennia: nevytrybuvanyi potentsial. Kyiv: Lybid, 560 p. [in Ukrainian]

Po dannym statisticheskogo otdela kievskoy gorodskoy upravy. (1918). Po dannym statisticheskogo otdela kievskoy gorodskoy upravy [According to the statistical department of the Kiev City Government]. Evreyskaya mysl, 17, 8 aprelya. [in Russian]

Pobudova ministerstva. (1918). Pobudova ministerstva [Ministry Building]. Visnyk Rady Narodnykh Ministriv UNR, 18 kvitnia. [in Ukrainian]

Potapenko, M.V. (2010). Polskyi demokratychnyi rukh u Naddniprianskii Ukraini (berezen 1917 kviten 1918 rr.) [Polish Democratic Movement in the Dnieper Ukraine (March 1917 - April 1918)]. Ukrainskyi istorychnyi zhurnal, (6), 90-105. [in Ukrainian]

Pro Tsentralnu Radu i Radu Narodnykh Ministriv. (1918). Kyiv: Vidrodzhennia. 96 p. [in Ukrainian]

Protest poliakiv. (1917). Protest poliakiv [Protest of the Poles]. Nova Rada, 11 lystopada. [in Ukrainian]

Prykazy po Sekretarstvu Polskykh Sprav. (1917). Prykazy po Sekretarstvu Polskykh Sprav [Orders for the Secretariat of Polish Affairs]. Visnyk Heneralnoho Sekretariatu UNR, (7), 23 hrudnia, 3. [in Ukrainian]

Pryvileiovana volia viry. (1918). Pryvileiovana volia viry [The privilege of faith]. Vidrodzhennia, 11 kvitnia. [in Ukrainian] 
Reyent, O. P. (2016). Ukrainski vyzvolni zmahannia 1917 - 1921 rokiv [The Ukrainian liberation struggle of 1917 - 1921]. Kyiv: Arii, 280 p. [in Ukrainian]

Skalsky, V. (2008). Politychne zhyttia polskoi hromady pid chas ukrainskoi revoliutsii (berezen 1917 kviten 1918 rr.) [Political life of the Polish community during the Ukrainian Revolution (March 1917-April 1918)]. Ukrainskyi istorychnyi zbirnyk, (11), 185-202. [in Ukrainian]

Soldatenko, V. F. (2008). Ukraina v revoliutsiinu dobu: Istorychni ese-khroniky [Ukraine in a revolutionary day: Historical essays-chronicles]. (In 4 vol. Vol. 1: Year of 1917). Kharkiv: Prapor, 560 p. [in Ukrainian]

Soldatenko, V. F. (2010). Ukraina v revoliutsiinu dobu: Istorychni ese-khroniky [Ukraine in a revolutionary day: Historical essays-chronicles]. (In 4 vol. Vol. 2: Year of 1918). Kyiv: Svitohliad, 411 p. [in Ukrainian]

Soldatenko, V. F. (2011). Revoliutsiina doba v Ukraini (1917 - 1920 roky): lohika piznannia, istorychni postati, kliuchovi epizody [Revolutionary era in Ukraine (1917-1920): logic of cognition, historical figures, key episodes]. Kyiv: Parlamentske vydavnytstvo, 568 p. [in Ukrainian]

Tsentralnyi derzhavnyi arkhiv vyshchykh orhaniv vlady ta upravlinnia Ukrainy (Central State Archive of the Higher Authorities and Administration of Ukraine - CSAHAAU)

V ministerstve po polskim delam. (1918). V ministerstve po polskim delam [In the Ministry of Polish Affairs]. Narodnoe delo, 18 aprelya. [in Russian]

Verstyuk, V. F. (1997). Ukrainska Tsentralna Rada [The Ukrainian Central Rada]. Kyiv: Zapovit. 344 p. [in Ukrainian]

Verstyuk, V. F. (2017). Vid "Velykoi Oktiabrskoi sotsyalystycheskoi revoliutsyy i grazhdanskoi voiny na Ukrayne (1917 - 1920)" do "Narysiv istorii Ukrainskoi revoliutsii" y dali: transformatsii doslidnytskoi paradyhmy [From the "Great October Socialist Revolution and the Civil War in Ukraine (1917 - 1920)" to "Essays on the History of the Ukrainian Revolution" and beyond: the transformation of the research paradigm]. Ukrainskyi istorychnyi zhurnal, (3), 8-23. [in Ukrainian]

Verstyuk, V. F. etc. (ed.). (1996). Ukrainska Tsentralna Rada. Dokumenty i materialy [The Ukrainian Central Rada. Documents and materials]. (In 2 vol. Vol.1: 4 March - 9 December 1917). Kyiv: Naukova dumka, 590 p. [in Ukrainian]

Verstyuk, V. F. etc. (ed.). (1996a). Ukrainska Tsentralna Rada. Dokumenty i materialy [The Ukrainian Central Rada. Documents and materials]. (In 2 vol. Vol. 2: 10 December 1917 - 29 April 1918). Kyiv: Naukova dumka, 420 p. [in Ukrainian]

Vidnyanskiy, S. (2012). Protsessy natsionalnogo samoopredeleniya na Bukovine v 1918 g., ee vklyuchenie v sostav rumyinskogo korolevstva i rumyinizatsiya avtohtonnogo ukrainskogo naseleniya kraya [The processes of national self-determination in Bukovina in 1918, its inclusion in the Romanian kingdom and the Romanization of the autochthonous Ukrainian population of the region]. Rusin, 2 (28), 23-34. [in Russian]

Zaretska, T. (2003). Polske naselennia UNR v dobu Ukrainskoi Tsentralnoi Rady (1917 - 1918 rr.) [Polish population of the UPR during the period of the Ukrainian Central Rada (1917-1918)]. Istoriohrafichni doslidzhennia v Ukraini, (13), 174-188. [in Ukrainian]

Zhvanko, L. (2013). Diialnist uriadovykh struktur Ukrainskoi Narodnoi Respubliky u spravi pidhotovky do repatriatsii bizhentsiv Pershoi svitovoi viiny (zyma 1917 - vesna 1918 rr.) [Activities of the Governmental structures of the Ukrainian People's Republic in the preparation for the repatriation of refugees of the First World War (winter 1917 - spring 1918)]. Problemy vyvchennia istorii Ukrainskoi revoliutsii 1917-1921 rr, (9), 139-167. [in Ukrainian]

The article was received on June 22, 2019. Article recommended for publishing 26/02/2020. 